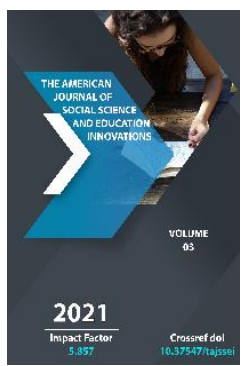

\title{
Principles And Methods Of Linguistic Competence
}

\section{Jumanazarov U.U.}

Doctor Of Philosophy In Pedagogical Sciences (PhD), Jizzakh State Pedagogical Institute, Uzbekistan

\section{Journal Website:} http://usajournalshub.c om/index,php/tajssei

Copyright: Original content from this work may be used under the terms of the creative commons attributes 4.0 licence.

\section{ABSTRACT}

The article is based on five principles (linguistic, didactic, pedagogical, psychological-psycholinguistic, and methodological) in teaching English and their contribution to the development and improvement of linguistic competencies of students in the field. It is said that these principles serve as the main sources in achieving the set educational and methodological goal, as well as the choice of methods, tools and techniques used in the process of learning a foreign language.

\section{KEYWORDS}

Linguistic competence, competence, ability, skill, principle, method, educational-methodical process, thinking, knowledge, skills.

\section{INTRODUCTION}

One of the urgent tasks is to define the principles used in teaching English to develop and improve the linguistic competencies of future English teachers. We therefore found it necessary to dwell briefly and describe them in this article. The scientific community and Methodist scholars are well aware that the principles of foreign language teaching 
methods were first identified in the last century (1965-1970) by E.N. Passov, but until now it was based on the general didactic principles proposed by Ya.A. Kamensky.

\section{THE MAIN FINDINGS AND RESULTS}

There are four principles (linguistic, didacticpedagogical, psychological-psycholinguistic and methodological) in teaching English and they directly contribute to the formation and development of linguistic competencies of students in the field. These principles are interrelated; they play the role of a program in achieving the set educational and methodological goal, and are selected and applied depending on the function of the methods, tools and techniques used in the process of learning a foreign language.

1. Linguistic principles. Foreign L.V.shcherba, G.E.Vedel, A.N.Leontev, A.A.Mirolyubov, V.A.Buxbinder, S.K.Folomkina, E.I.Passov, A.A.Shakirova, $V$ Methodists such as $L$. Scalkin, L. Freeman, S. Thornberry, and D. Crystal have conducted extensive research on this principle. Summarizing the general description of the issues raised and identified in them, applied in practice, it is appropriate to define as follows: 1 . The principle of taking into account the experience of the native language; 2 . The principle of systematization (teaching of oral and language materials are organized for communicative purposes, introduced through grammatical units and lexical methods); 3. The principle of concentrationism (implies that the learning material is constantly expanded through the transition from easy to difficult, from reinforcement to new); 4. The principle of functionality (language material is applied according to the content of education, grammar material is taught communicatively. This principle is determined by the objectives of foreign language teaching); 5. The principle of minimization or limitation (types of speech activities are limited according to the level of foreign language proficiency); 6. The principle of active (activity) (involves working on the language material taught in the application of all types of speech activities); 7. The principle of passivity (consists only in working on language materials that are taught to be used in the form of listening comprehension and reading speech activities); 8 . The principle of stylistic differentiation (foreign language is taught by taking into account the specific features of different speech patterns, for example, scientific, artistic, popular, formal styles); 9. The principle of taking into account intercultural cooperation; the principle of consciousness.

2. Didactic-pedagogical principles. These principles were developed by foreign scientists Ya.A. Kamensky, L.S. Vygotsky, L.V. Shcherba, I.V. Rakhmanov, A.Sh. Shklyaeva, G.E. Vedel, I.L. Bim, A.N. Leontev, R.K.Minyar-Beloruchev, E.I.Passov, I.A.Zimnyaya, N.D.Galskogo, N.I.Gez, Yu.K.Babanskiy, A.V.Khutorskiy, S.Tornberi, It was identified as a result of many years of research by G. Wells et al. and incorporated into the educational process. Summarizing these, we emphasize the following: 1. Linking the study material with life; 2 . Consciousness and activity of the student with the help of the teacher; 3. Comprehensibility and simplicity; 4. Relationship between practice and theory or science; 5. Clear delivery of training materials; 6 . 
Demonstration; 7. Strong acquisition of skills; 8. Relationship with sciences; 9. The advantage of active movement of the student in the learning process; 10. Thorough mastering; 11. Productivity; 12. Mobility (efficiency. or activity; 13. Individual approach; 14. Ease-difficulty or adaptability to student strength; 15. Interaction of cultures; 16 . Teach decisionmaking or develop a common outlook; 17. Use and application of alternative methods and tools according to the content and assignment; 18 . Selection of the necessary conditions for teaching; Education in the aesthetic spirit; 20. Teaching to work as a team; 21. Upbringing through teaching.

3. Psychological principles. These principles have been developed and put into practice by foreign scientists L.S.Vygotskiy, G.E.Vedel, R.K.Minyar-Beloruchev, M.D.Berlits, V.A.Artemov, K.B.Esipovich, A.G.Kavalev, T.A.Kozlova, A.I.Surygin, J. Piaje and others. They are: 1 . The principle of student creativity; 2. Verbalization (teaching by working on oral speech); 3. Correlation (language units are specially selected for the acquisition of speech skills, English is taught based on speech topics); 4. Motivation (interest, inclination) in learning English; 5. Intrinsic motivation and the principle of self; 6 . Gradual formation of speech skills; 7. Taking into account the individual-psychological characteristics of the student (personal, subjective, individual); 8. Consideration of the process of adaptation; 9. In the course of the lesson, the teacher becomes a passive individual, and students become an active subject, and so on.

Based on the above principles, the following psychological and psycholinguistic principles were identified during the research and experimental work: 1. Encouragement, motivation based on the positive emotional characteristics of the student; 2 . Development of autonomous characteristics of the student (understands what he is learning English, understands his responsibilities, is able to repeat what he has learned and assess the extent to which he has learned); 3. Selection of teaching methods according to the age characteristics of the student; 4 . To teach students how to cope with existing emotional problems in the lives of their peers in the countries where the language is studied; 5 . Develop students' interest in learning English; 6. Taking into account the personal and individual interests of students; 7. Develop students' self-confidence; 8 . Attention and so on.

1. Methodical principles. Methodological principles have been thoroughly studied and popularized by foreign scholars such as L.V.shcherba, G.Palmer, R.K.MinyarBeloruchev, N.D.Galskogo, N.I.Gez, V.L.Skalkin, M.B.Lyaxovitsskiy, A.N.Shamov, E. I.Passov, S. Richards and Rogers, S. Thornberry, U. Penny, L. Freeman, R. Akbari. It is expedient to study the methodological principles in the following three groups, depending on the object, purpose and scope:

a) The purpose of the general methodological principles is communicativeness, priority / performance of exercises, limited or integrated teaching of the teaching material, repetition of previously taught and studied teaching material in the lessons, ensuring continuity;

b) The purpose and content of specific methodological principles include 
approximation to natural pronunciation (modeling), model-based learning, teaching based on an integrated approach, the promotion of oral speech, the use of acceleration / acceleration, cognitive competence, automation of language units;

c) Special methodological principles include working on types of speech activities and language materials, promotion of oral speech, stimulating students' speaking and thinking skills, teaching English within specialties, and so on.

Media reports confirm that the pandemic situation in the world, which began in the last quarter of 2019 and is still ongoing, has affected the teaching of foreign languages, as well as the subjects taught in all educational institutions. Taking into account the current conditions in our country, we have identified and implemented the following didactic principles for the development of linguistic competence of students in the process of effective organization of foreign language learning and research: 1. Teaching using cognitive technologies; 2 . Completion of assignments by recording sounds; 3. Learning through the activity of friends; 4 . Short videos and presentations; 5. Good training is important; 6. Use age-appropriate authentic texts; 7. Use appropriate cultural stereotypes that teach the culture of other countries; 8 . Use of multimedia educational materials; 9. Error correction; 10. Encourage students to complete assignments, etc.

Another of the issues raised in this chapter of the study is to identify the methods of teaching English to students in the field and their importance in the development of linguistic competencies; most importantly, we considered it of great scientific and practical importance to describe the extent to which the skills acquired by learners through these methods can be.

In the history of world civilization, the study of foreign languages in addition to the native language, which forms the thinking of the individual, is widely used. After all, establishing different relationships between peoples requires knowledge of their languages first. It is known from the world experience that a foreign language is taught at different times using different methods. In particular, until the fourth quarter of the XIX century and the first quarter of the $X X$ century, foreign languages were taught by the method of translation. After the reform of the European foreign language teaching methodology, a direct method was developed. From this period, speech activities in any foreign language began to be taught. As a result, many new methods have been proposed. The modernized conscious-comparative method has been widely used in Russia. Later, the audiolingual method was popularized by U.S. experts, and the audiovisual method was widely used in France. Since the 1980s, the communicative methods that are popular in Europe, and more precisely in the UK, have been widely used by experts in English-speaking countries and others. Applied linguists Jacques S. Richards and Theodore S. Rodgers acknowledge that, according to Raman Akbari, the post-Methods Pedagogy Era has arrived [1, pp. 641-652, 231].

We found it necessary to describe the sequence of methods used and the skills acquired by students in the following order:

1. Grammar-translation or classical method (GT / CM) appeared in the early twentieth century. This method was used to strengthen students' reading skills and help them appreciate foreign 
language literature. As a result, students have mastered the grammar of their native language effectively. The language material is taught in a deductive way (first a rule is given, and then explained with examples). The skills acquired through this method were: students translated what they read from literary books or in English; insufficient ability to communicate, but the main practical goal is to focus on reading, writing, speaking and listening comprehension, with little emphasis on pronunciation training; students were given the opportunity to determine the equivalents of words learned in English that are important to the teacher in the presence of the mother tongue. As a result, grammatical units in English have been successfully mastered.

2. Correct, inductive or natural method (C/I/N.M). It has been used for many years for communicative purposes in foreign language teaching, the only rule being the abandonment of the mother tongue altogether. Handouts and illustrations were used. The grammar is taught in a minimum inductive (first expressed in speech, then the rule is explained) method. The skills acquired through this method were: complex reading, reading and speaking comprehension; the teaching of specific linguistic units was carried out through pictures, demonstrative materials; the language material was demonstrated without the use of the mother tongue; extensive attention is paid to pronunciation training; the development of the record is given special consideration; the learner is given new information about the lifestyle of the learners of the language being studied, and is taught to compose speech situational sentences using everyday lexical units.

3. Oral approach or situational language teaching method (SLTM). The founders of this method were Harold Palmer, who later reworked it by $\mathrm{S}$. Thornberry. Emphasis is placed on word structure, the use of words in structurally different sentences. When this method was used, the learner was engaged in the independent acquisition of English as a foreign language. Skills acquired through this method: language teaching takes into account the development of oral speech; language material is not written, but oral and language units are taught in different situational situations; reading and writing are introduced after lexical and grammatical units are firmly taught; grammar is taught on the basis of an inductive approach; in the course of the lesson, communication begins in a variety of extracurricular life situations.

4. Audio-linguistic or oral speech-based method (ALM). In 1945, this method was proposed by Charles Friese, an applied linguist at the University of Michigan, sometimes referred to in the West as the Michigan method. No time was spent teaching grammar rules in this method. Skills acquired through this method: teaching of speech situations is carried out in different natural contexts; the teacher is the main subject; in English learning, for example, various dialogues and situations are read or narrated by the teacher, and then students return in unison; linguistic units are taught to pronounce correctly; the teacher acts as an active subject and frequently motivates students.

5. Silent teaching method (STM). This method was founded in the 1960 s by Galib 
Kattegno. Different colored figures represented different sounds. Pupils pronounced the words themselves using different letters or colored figures, composing different sentences. The skills acquired through this method are: based on the idea of constructivism; students compose sentences in a way that reinforces memory; interest in language learning as a group increases; easy to control the level of English learning; all types of speech activities - integrative reinforcement.

6. Total/Physical Response Method (TPRM). This method was proposed by John Asher. Mainly suitable for teaching foreign languages to younger students. Skills acquired through this method: begins to acquire language material through physical actions by listening to the teacher. For example, they can verbally express words and phrases they have learned in English; repeat the linguistic units learned with the help of the teacher in unison.

7. Collective Language Learning Method (CLLM) (called the humanistic method). This method, applied by Charles A. Carren, was mainly preferred in teaching foreign languages to adults. Language learners worked in various small groups. Foreign language teaching was carried out by dividing the students into different subgroups. Skills acquired through this method: the teacher is considered as a consultant in the classroom, and the student as a client; no emphasis is placed on learning language material through textbooks; students use their native language during the lesson; the teacher translates their thoughts into English; they record the teacher's speech on cell phones or audio tape, then use the teacher to summarize their thoughts and repeat them in unison.

8. The method of disuggestopidia (DeSM) was proposed by George Lozanov, who studied figurative English using live actions under music. The knowledge acquired through this method: the teacher demonstrates to students the words in English, using a variety of actions in the process of teaching sentences; students learn to recite English in unison with the teacher's actions; learning English becomes an interesting process.

\section{CONCLUSION}

To conclude, due to the fact that today the communicative method is widely used in almost all educational institutions; Experts are aware that this method is interpreted as an approach in Western countries. Currently, English is taught in Uzbekistan at different stages of education, using different methods. In particular, audio-lingual, Audio-lingual and Audio-visual, Total Physical Response (TPR), Communicative language teaching (CLT), Competence-Based Teaching, Cooperative Language Teaching, Content-Based Education, and Task-Based Teaching are popular.

\section{REFERENCES}

1. Jack C.Richards and Theodore S.Rodgers. Approaches and Methods in Language Teaching: Third Edition.: 2014. - pp. 245270.

2. Ramin Akbari. Postmethod Discource and Practice. The Forum. TESOL Quarterly. Vol. 42, \# 4, December 2008. - pp. 641-652.

3. Rozmetova M.Sh. Technologies for developing competencies in teaching English to students in grades 5-7 of general secondary education. - Doctoral dissertation for the degree of Doctor of 
The American Journal of Social Science and Education Innovations (ISSN - 2689-100x)

Published: April 27, 2021 | Pages: 151-157

Doi : https://doi.org/10.37547/tajssei/Volume03Issue04-23

2021: 5.857

OCLC - 1121105668

Philosophy (PhD) in Pedagogical Sciences.

- p. 231. (Рўзметова М.Ш. Умумий ўрта таълим 5-7 синф ўқувчиларига инглиз

тилини ўқитишда компетенцияларни

ривожлантириш технологиялар. -

Педагогика фанлари бўйича фалсафа

доктори ((PhD) ) илмий даражасини

олиш учун тайёрланган ДДИ. - 231 б.)

4. Ismatullayeva, N. R. (2020). Probability Prediction Strategy In Simultaneous Interpretation. CURRENT RESEARCH JOURNAL OF PHILOLOGICAL SCIENCES, 1(01), 1-6. 